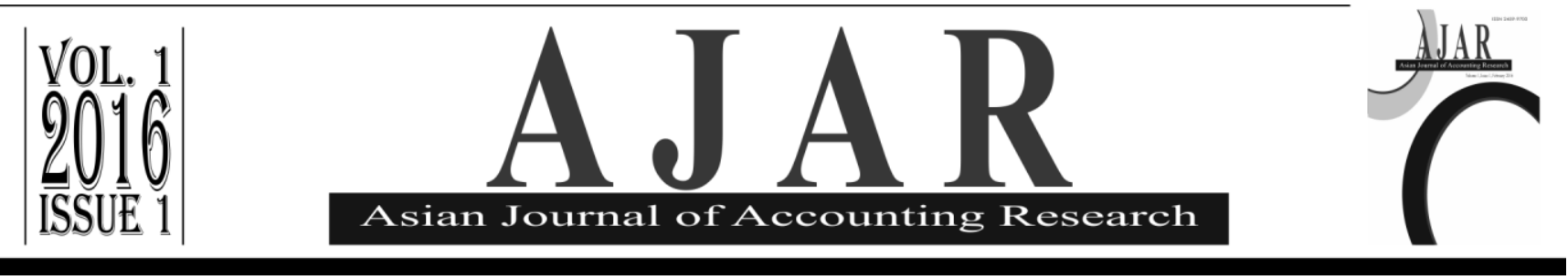

\title{
The Antecedents of Non-Unqualified Opinions of Local Governments Financial Statements: A Study on Counties and Cities in East Java Province
}

\author{
Sri Ningsih* \\ *Universitas Airlangga
}

ARTICLE INFO

Article history:

Received 30 September 2015

Accepted 27 January 2016

Available online 29 February 2016

Keywords:

Content Analysis

LGFS

Audit Opinion

Non-unqualified Opinion

\begin{abstract}
A B S T R A C T
Local Government in Indonesia annually publishes Local Government Financial Statements (LGFS) for helping their stakeholders in making decisions. Audit Opinion of the LGFS for counties and cities in East Java Province during the last 8 years (2006-2013) showed a quite astonishing result. From all of 301 financial statements, only 45 LGFS (14.95\%) obtained Unqualified Opinion, other financial statements (256 or $85.05 \%$ ) received Non-Unqualified Opinion. This study aims to analyze the accounts and problems in the accounts which cause LGFS obtain Non-Unqualified Opinion. Using content analysis with NVIVO10 applications, this study analyzed 256 audit opinions of the LGFS of counties and cities in East Java during 20062013 that obtained Non-Unqualified Opinion to identify the accounts and problems in the accounts which cause LGFS obtain Non-Unqualified Opinion. The results showed that the most frequent accounts as an exception in the audit opinion are the accounts on Budget Realization Report (BR) with the frequency of occurrence as much as 6628 times. The Balance Sheet (BS) accounts was at the second place with the total frequency of occurrence 4206 times. And last, there was a Cash Flow Statement (CF) account with the frequency of occurrence as much as 693 times. In BR, the most frequent account which appears as an exception is spending account (as much as 4198 times), while the assets are the most frequent accounts as an exception in the Balance Sheet (as much as 4206 times). The problem with the accounts that often appear as an exception was mainly due to the weakness of the Internal Control System (ICS), followed by non-compliance with the provisions of law and the last problem is in-economies, inefficiency and ineffectiveness.
\end{abstract}

\section{Introduction}

Local Government Financial Statement (LGFS) is a form of public accountability presented to the stakeholders. Mardiasmo (2006) stated that the LGFS is a means of accountability to the internal or external parties. For internal parties, the financial statements act as media to report to superiors about programs and activities that have been implemented during the fiscal year and also play an important role for Government Units performance evaluation. The LGFS also provide information to external parties about the use of funds from the public that is expected to help users of financial statements in the decisions making.

The financial statements will be useful for decisions making if the LGFS produced by the Local Government meet the expected quality. The financial statements are considered to have an acceptable quality if complying with the qualitative characteristics specified in the standard, in this case the Government Accounting Standards (GAS) as stated in Government Regulation No. 24/2005. One way to improve the quality of financial statements (LGFS) is to conduct an audit by an independent auditor. In accordance with the Provisions of Law No. 15/2004, institution that has an obligation to audit LGFS is Supreme Audit Agency (SAA). According to Law No. 15/2004, the final results of audit process conducted by SAA is an audit opinion, which includes four kinds of opinion: Unqualified Opinion, Qualified Opinion, Adverse Opinion, and Disclaimer Opinion. From all of these audit opinion, Unqualified Opinion occupies the highest position so each Local Government is encouraged to 
achieve Unqualified Opinion for their LGFS. Unqualified Opinion represents a good quality of LGFS in accordance with the standards.

Audit opinion of LGFS for counties and cities in East Java during the last 8 years (2006-2013) shows astounding results. From the total of 301 LGFS, 198(65.78\%) LGFS obtained Qualified Opinion, 48(15.95\%) LGFS gained Adverse Opinion and 10(3.32\%) LGFS acquired Disclaimer Opinion. Only 45 LGFS (14.95\%) received an Unqualified Opinion. These results show that there are many LGFS which did not meet the requirements as stated in the standard. The facts that only few LGFS obtained an Unqualified Opinion motivate researchers to further investigate what causes LGFS of counties and cities in East Java obtained NonUnqualified Opinion. In this paper, Non-Unqualified Opinions refers to Qualified Opinion, Adverse Opinion, and Disclaimer opinion. The research questions which need to be answered are: (1)What accounts that cause LGFS obtained Non-Unqualified Opinions? (2)What problems arise in the group of accounts that cause LGFS obtain Non-Unqualified Opinion?

In accordance with the proposed research questions, the purpose of this research is to identify the group of accounts and problems that arise in the group of accounts in LGFS which cause LGFS obtain Non-Unqualified Opinions. The main theory used in this research is the Agency Theory, where the local government as the agents is responsible for publishing the financial statements to the users especially for financial statements that act as principal. To protect the users who do not know much about the actual conditions in the local government from the possibility of manipulation, the financial statements should be audited by an independent auditor.

The analysis of 256 audit opinions from SAA of the counties and cities Government in East Java showed Non-Unqualified Opinion for the period 2006 to 2013. This analysis was conducted by using a qualitative approach. The research instrument which used content analysis was carried out with NVIVO 10 application/program to identify accounts and problems in the accounts causing LGFS obtain Non-Unqualified Opinion.

This paper will be divided into some sections. Next sections will present the review of related literature and theoretical framework as the bases of the research. The methodology and data analysis used by researchers to answer the research questions will be articulated afterwards, and will be followed by the findings of the research, limitation of the study, conclusions, and research implications..

\section{Literature Review}

\subsection{Previous Research}

The research conducted by Subehan (2012) which analyzed 28 Audit Opinions of SAA for counties and cities LGFS in East Java province for the fiscal year 2011 reported three main results. First, basically there are two basic conditions for the SAA to determine LGFS for getting non-unqualified opinion: the limitation of scope or insufficiency of evidence and distortion of accounting principles that have material value in LGFS. Second, Balance Sheet account is the most frequent account as an exception to the SAA opinion and the most frequent account is a permanent investment. Third, insufficient or incomplete documents are the most frequent problem appearing as an exception in the group of non-compliance issues with laws and regulations. The most problems that often appear as an exception in the weaknesses of internal control are debt accounts and non-permanent investment. In-economies, inefficiencies and ineffectiveness are not the issues or the causes for not obtaining an Unqualified Opinion.

Research conducted by Sari et al. (2010) analyzed 19 Audit Opinions issued by SAA for counties and cities in West Sumatra that received Qualified Opinion during 2 year audit. It showed that the account which was the main cause of LGFS obtaining Qualified Opinion was the Balance Sheet and the Budget Realization accounts. On Balance Sheet, the main issue is current assets, while in the Budget Realization the main issue is the operating expenditure and revenue. The study also revealed that the main problem on the account is noncompliance with government accounting standards, non-compliance with the laws and the weakness of the internal control system.

This research aims to refine the previous studies by expanding the scope of research and using different methods of data analysis. Subehan (2012) analyzed only 28 LGFS of counties and cities in East Java i.e. for only 2011 fiscal year, whereas Sari et al. (2010) analyzed only 19 LGFS of counties and cities in West Sumatra who acquired Qualified Opinion for 2 years audit. This study analyzed 256 audit reports of LGFS in counties and cities in East Java Province which gained Non-Unqualified Opinion during the 8 years from 2006 to 2013, in which 198 LGFS obtained Qualified Opinion, 48 gained Adverse Opinion and 10 obtained Disclaimer Opinion by using content analysis with NVIVO. The purpose of expanding the scope of the research and also using special software is to achieve more accurate description of the accounts and the problems causing LGFS to get NonUnqualified Opinion for long period since government issuing Government Accounting Standard (GAS) based on cash toward accrual basis. 


\subsection{Theoretical Framework}

\subsubsection{Agency Theory}

Anthony and Govindarajan (1995) argue that agency theory explains the relationship between the two parties, agents and principal, in which agents acquire delegation of authority from the principal to make decisions and to act on behalf of and for the benefit of the principal. As consequences, the agent will be accountable for all actions that have been taken to the principal. Jensen and Meckling (1976) describe the agency theory as an interaction or relationship between the owner and those who manage a business. The Relationship or interaction is expressed formally based on a contract that describes the rights and obligations of owners and those who manage the business.

Mahmudi (2007) stated that in public sector organizations, especially in governmental organizations, there is also a relationship that represents the agency theory, where societies or citizens who act as a principal, while the government act as an agent. Societies or people as the principal mandate the government to manage natural resources and the various sources of revenues derived from the public, such as taxes, levies and others to be managed for the prosperity and welfare of the societies. Government as an agent has an obligation to report the result of resources management entrusted to the societies or people as a principal.

Based on agency theory, there is no guarantee that the agency (government) always acts in the interest of the principal (the public). Government as an agent has an opportunistic behavior that he acted in the interests of his own welfare, not for the people's benefits (Watts and Zimmerman, 1986; Godfrey et al., 1997). The main problem that often arises in an agency relationship is the presence of information asymmetry, where one party has more information than others. Government as an agent often has more information about the actual performance of the organization, while the society as a principal often obtain limited information about government performance or even they have no information at all. Giving information to the public about the government's performance (in the form of financial statements) is one way to reduce the information asymmetry in the public sector, especially in the government.

\subsubsection{Quality of Local Government Financial Statements}

Local Government Financial Statement (LGFS) is a form of government accountability for the resources they manage. Mardiasmo (2006) stated that the publication of LGFS to stakeholders is a form of Local Government internal accountability as well as to external parties, especially for the public and other users of financial statements as one of the considerations for decision-making. To be used as a tool for decision-making, the financial statement prepared by the Local Government should meet the information quality based on standards, in this case the Government Accounting Standards (GAS).

The Governmental Accounting Standard in Indonesia was Government Regulation No. 24/2005 about cash toward accrual basis which was used until 2014. The newest Government Accounting Standard about an accrual basis has officially been implemented in 2015. In accordance to the GAS 2005, Local Governments are required to prepare financial statements which consist of Budget Realization Report (BR), Balance Sheet (BS), Cash Flow Statement (CF), and Notes to the Financial Statements (NTFS). The conceptual framework of GAS explained that in order to provide adequate quality for decision making, the information provided in LGFS should be relevant, reliable, comparable, and understandable.

\subsubsection{Audit of Local Government Financial Statements}

To protect the users of local government financial statements from the possibility of manipulation in the financial statements because they might not know much about the real condition of local government, LGFS must be audited by an independent third party (Mahmudi, 2007). In accordance with Law No. 15/2004 about Audit of Management and Responsibility of the State Finance and Law No. 15/2006 regarding the Audit Board, the institution which has an obligation to audit the LGFS is Supreme Audit Agency (SAA). The final result of audit taken by SAA is an opinion about the LGFS which consists of Unqualified Opinion, Qualified Opinion, Adverse opinion and Disclaimer Opinion.

During an investigation of the LGFS, the Indonesian SAA guided by the State of Auditing Standards which have four reporting standards were set up by IAPI and six additional standards (John \& Setiawan, 2009). In order to classify the findings obtained during the audit process of the LGFS, SAA has issued Decree No. 5 / K / I-XIII.2 / 8/2010 on Technical Guidelines for Coding Examination Findings. In accordance with the Decision of the SAA No. 5 / K / I-XIII.2 / 8/2010, the findings about problems in the accounts that cause LGFS obtain NonUnqualified Opinions are classified into three categories, namely: (1) non-compliance with the provisions of the legislation and laws, (2) the weakness of the internal control system, and (3) in-economies, inefficiency and ineffectiveness (3E). 


\section{Research Method}

\subsection{Research Approach}

To answer the research questions, qualitative research methods were used. Moleong (2005) explained that qualitative research is an approach that uses natural setting, yet it does not use a specific treatment to understand a specific phenomenon. In fact, many LGFS get Non-Unqualified Opinion (in case LGFS get Qualified Opinion, Adverse Opinion and Disclaimer Opinion) which is a phenomenon to be observed in this study. Interpretive paradigm especially phenomenology was applied in this study, where the facts are seen as something unique, facts have a specific context and meaning, and they are essential in understanding the social meaning. Interpretive paradigm views the facts as liquid (not rigid) in the system of meaning and assumes that the understanding of a common sense is real, stable, and sustainable over time (Neuman, 2011). A qualitative approach with interpretive paradigm (phenomenology) was chosen for this study because this research was not intended to examine the relationship between variables, but this is intended to identify and describe the group of accounts and the problems arise in the accounts that cause LGFS obtain Non-Unqualified Opinion.

\subsection{Unit Analysis}

The unit analysis of this study is Audit report of counties and cities Government in the East Java. East Java was selected as the unit of analysis because it has the highest number of Local Government in Indonesia which is consists of 29 counties and 9 cities Government.

\subsection{Research Instrument}

This study uses content analysis as an instrument. Content analysis is a method to capture the contents of a message or document (Shauki, 2014). Churyk et al. (2008) state that content analysis is a systematic technique to categorize words into categories of content by using certain rules of coding. Krippendorff (2004) states that content analysis as a research technique to prepare and draw a valid conclusion from the data set according to the context. Furthermore, Krippendorff (2004) explains that the excess of content analysis lies in its ability to provide the basis for a conclusion in a large number of texts by using a treatment in a systematic manner. Content analysis ensures that all unit analysis obtain equal treatment, no matter whether they are inputted first or the last time in the process of analysis. This study uses content analysis because it involves a large amount of data, in the form of text from the three main types of local government financial report consisting of Budget Realization, Balance Sheet, and Cash Flow Statement for 8 years. There are many different accounts and problems that influence Indonesian SAA to give Non- Unqualified Opinion for each year that required a systematic technique to identify the accounts and the problems arise in that accounts which cause LGFS obtain Non-Unqualified Opinion.

\subsection{Research Data}

Krippendorff (2004) states that the data suitably analyzed using content analysis include oral discourse, written documents, visual representations usually delivered through mass media such as newspapers, magazines, books, radio, films , commix and television programs. All of them are in written/text form. The data in this study consisted of 256 audit opinions of local government financial statements (LGFS) in East Java for the period 2006 to 2013, where 198 LGFS obtained Qualified Opinion, 48 LGFS obtained Adverse Opinion and 10 LGFS obtained a Disclaimer Opinion. All Data of Audit Report in pdf format has been converted into doc format to get consistencies for further data processing. Recapitulation Audit Opinion of counties and cities financial statement in East Java Province for 2006-2013 presented in Table 1.

Table 1

Recapitulation Audit Opinion of LGFS for Counties and Cities in East Java Province 2006-2013

\begin{tabular}{cccccccccc}
\hline Audit Opinions & 2006 & 2007 & 2008 & 2009 & 2010 & 2011 & 2012 & 2013 \\
\hline Unqualified Opinion & 1 & 0 & 0 & 0 & 5 & 10 & 12 & 26 \\
Qualified Opinion & 30 & 2 & 27 & 35 & 32 & 26 & 26 & 0 \\
Adverse Opinion & 5 & 36 & 5 & 1 & 0 & 0 & 0 & 0 \\
Disclaimer Opinion & 0 & 0 & 6 & 2 & 1 & 38 & 38 \\
Total & 36 & 38 & 38 & 38 & 38 & 37 & 38 \\
\hline
\end{tabular}

\subsection{Data Analysis}

Content analysis in this study is done by using the NVIVO 10 application. To obtain valid and reliable 
conclusions, qualitative content analysis was done which involved a series of clear and systematic data processing procedures. Krippendorff (2004) explains that research using content analysis in generally has 6 stages which are also implemented in this study, namely: (a) Design, (b) Determine the Unit Analysis, (c) Determine Sample, (d) Process Encoding (Coding), (e) Drawing Conclusions (Drawing inferences), (f) Validate (Validation).

\section{Findings}

\subsection{The Accounts Causing LGFS Obtain Non-Unqualified Opinion}

To determine the accounts that cause LGFS obtain Non-Unqualified Opinion, we use word frequency to identify keywords associated with "account" for each type of report. The most frequent words appearing then were classified according to the primary account that existed in each type of three main categories of local government financial statements. The results of word frequency analysis are presented in Table 2.

Table 2.

Category Content Analysis for Exception Accounts

\begin{tabular}{|c|c|c|}
\hline Category & Theme & Key word \\
\hline Budget Realization & Revenue & Revenue, Income, Earning, Retribution, Tax, Gross, Dividend, BUMD. \\
\hline Report & Expenditure (Spending) & $\begin{array}{l}\text { Expenditure, Capital, Goods and Services, Social, Grants, Personnel, } \\
\text { Interest, Subsidy, Unexpected, Maintenance, Transfer, Honorarium. }\end{array}$ \\
\hline & Financing & $\begin{array}{l}\text { Equity, Revolving, Fund, Debt, Loan, Establishment, Reserve, Divestment, } \\
\text { Budget Surplus, Permanent, Non permanent, installment, payment }\end{array}$ \\
\hline \multirow[t]{3}{*}{ Balance Sheet } & Asset & $\begin{array}{l}\text { Asset, Inventory, Investment, Land, Receivables, Construction, Building, } \\
\text { Road, Machine, Equipment Network, Irrigation, Vehicles, Installation, Bridge, } \\
\text { Capitalization, Deposit, shrinkage. }\end{array}$ \\
\hline & Liabilities & Obligation, Liabilities, PFK \\
\hline & Equity & Equity \\
\hline Cash Flow & Operating Activities & Flow \\
\hline \multirow{3}{*}{ Statement } & Investment Activities & - \\
\hline & Financing Activities & - \\
\hline & Non Budgetary Activities & PFK \\
\hline
\end{tabular}

The results of word frequency showed that the most frequent accounts which appeared as an exception or as the causes in the opinion paragraph are the accounts of the Budget Realization Report with 6628 times of appearance, followed by accounts in the Balance Sheet with 4206 times appearance, and the last are accounts in the Statement of Cash Flows with 693 times appearance. The account recapitulation of frequency appearance of the accounts in the exception paragraph for each type of report is presented in Figure 1.

Figure 1

Recapitulation Frequency of Appearance Exception Accounts in

Local Government Financial Statement

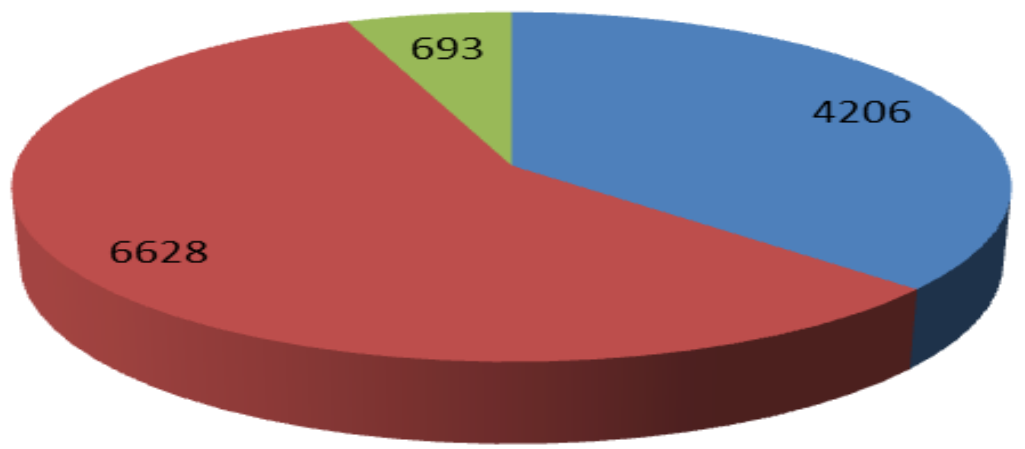

Balance Sheet

Budget Realization (LRA)

Cash Flow (LAK) 


\subsubsection{Exceptions in The Accounts of The Budget Realization Report}

The recapitulation frequency presented in Figure 1. shows that the accounts in the Budget Realization Reports are the most frequent accounts that appear as an exception or as a cause in the opinion paragraph of audit report by SAA with 6628 times frequency of appearance. The key word classification analysis of Budget Realization Reports indicates that the most frequent account in the opinion paragraph of audit report by SAA are Spending account with the frequency of appearance 4198 times, followed by the accounts of financing with the frequency of appearance 1476 times and the last is the revenue accounts with frequency of appearance 954 times. The frequency of appearance recapitulation in the Budget Realization Report is presented in Figure 2.

Figure 2

Recapitulation Frequency of Appearance Account in Budget Realization Report

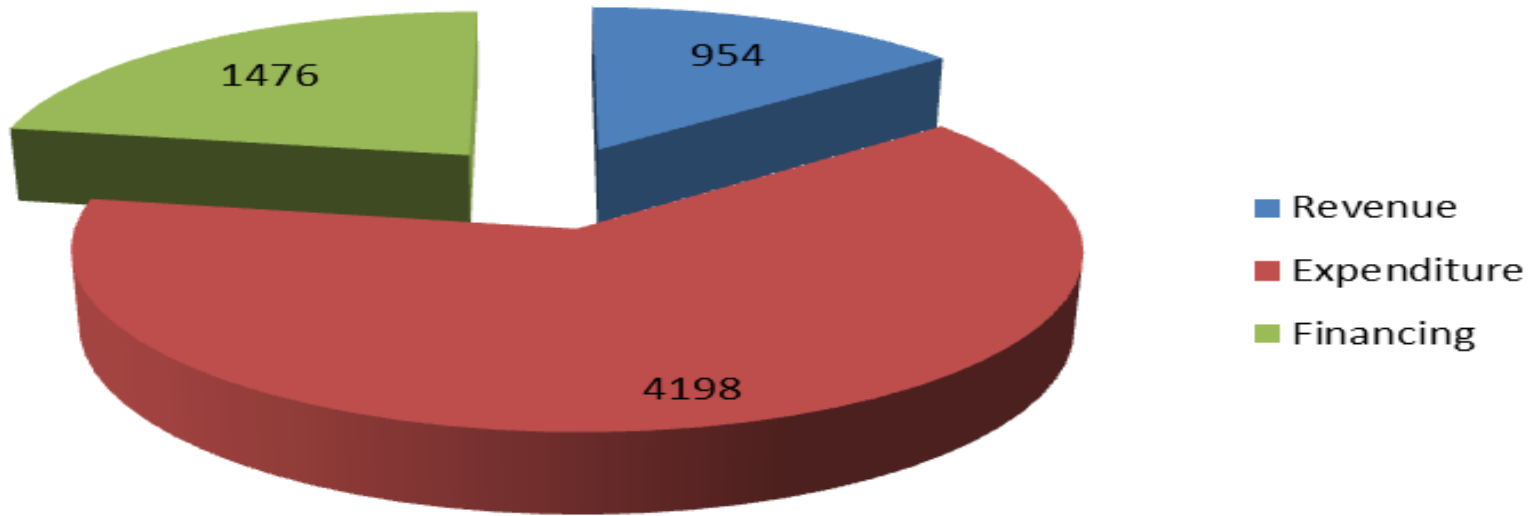

\subsubsection{Revenue Accounts}

The summary of frequency occurrence in Budget Realization Report indicates that revenue account is the least frequent account causing the local government financial statements to get Non-Unqualified Opinion with frequency of appearance 954 times (see Figure 2). In this case, the problems are mainly related to the account of Other Income, Retribution Income, Tax Income, calculating gross income, and income from profit enterprises.

\subsubsection{Expenditure (Spending) Accounts}

Expenditure (spending) account is an account that has the highest frequency as a cause of LGFS obtain Non-Unqualified Opinion, with a frequency of appearance 4198 times. Based on results analysis of word frequency, expenditure accounts which appear as an exception (from highest to lowest) include: Capital Expenditure, Expenditure on Goods and Services, Social Expenditure, Grants Expenditure, Personnel Expenditures, Interest Expenditure, Subsidy Expenditure, Unexpected Expenditure, Maintenance and Transfer Expenditure. The details of Expenditure accounts that become the major cause of LGFS obtain NonUnqualified Opinion are presented in Figure 3.

Figure 3

Recapitulation Frequency of Appearance Expenditure (Spending) Accounts

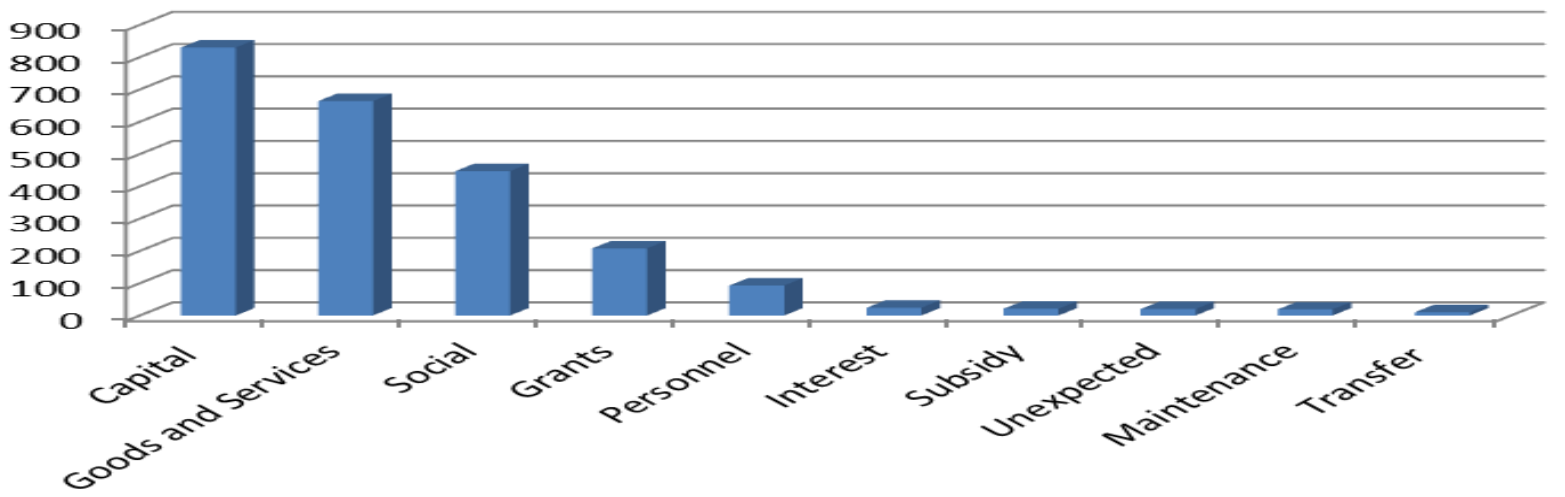




\subsubsection{Financing Accounts}

The recapitulation of frequency of occurrence in the Budget Realization Report shows thatFinancing Accounts were at the second place as the account causing LGFS obtain Non-Unqualified Opinion with frequency of occurrence as much as 1476 times (see Figure 2). The word frequency analysis shows that the accounts of financing as an exception account comprise: Equity, Revolving Fund, Debt/Loan, Establishment of the Reserve Fund, Divestment, and the use of Budget Surplus.

\subsubsection{Exceptions in Balance Sheet Accounts}

The recapitulation of frequency shown in Figure 1. reveals that balance sheet reports are at the second place as an exception or as a cause in the opinion paragraph of audit report by SAA with frequency of appearance 4206 times. The key word classification of the word frequency analysis shows assets are the most frequent accounts which appeared 4107 times, followed by liability accounts with frequency of appearance 71 times and the last is the equity accounts with frequency of appearance 28 times. The frequency of occurrence recapitulation in the Balance Sheet Report is presented in Figure 4.

Figure 4

Recapitulation Frequency of Appearance Account in Balance Sheet

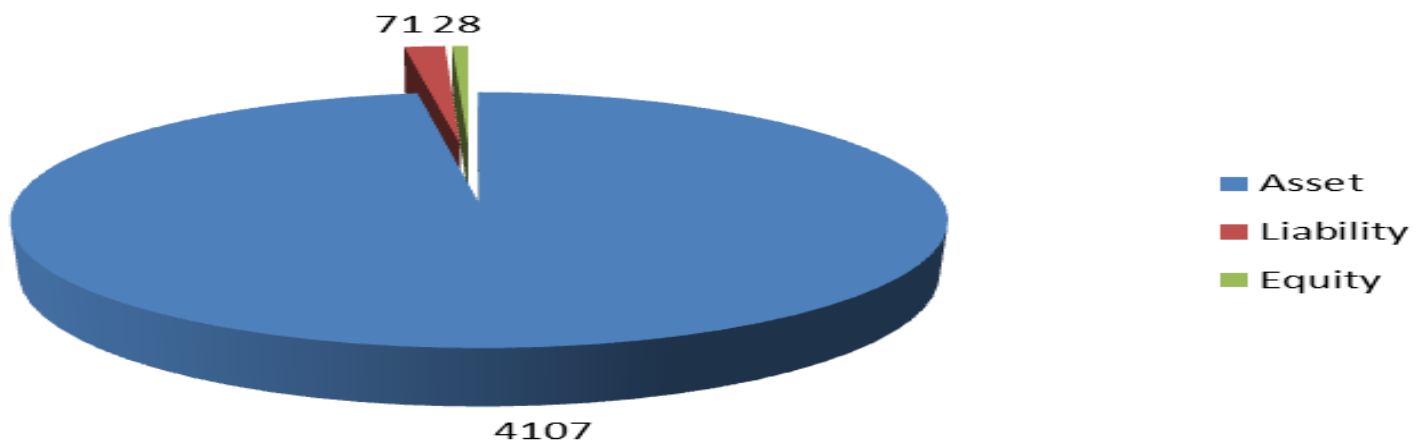

\subsubsection{Asset Accounts}

Asset is the most frequent account that causes local government financial statements to get NonUnqualified Opinion with frequency of appearance 4107 times (see Figure 4.). The word frequency results indicate that assets causing LGFS to get non-unqualified opinion (from the highest to the lowest) are: (1) Inventory, (2) Investment, (3) Land, (4) Receivables, (5)Building-1, (6) Building-2, (7) Road, (8)Machine, (9)Equipment (10) Network, (11) Irrigation (12)Construction, (13) Vehicles, (14)Installation, and (15)Bridge. The details of Assets that cause LGFS obtain Non-Unqualified Opinion is presented in Figure 5.

Figure 5

Recapitulation Frequency of Appearance Asset Accounts

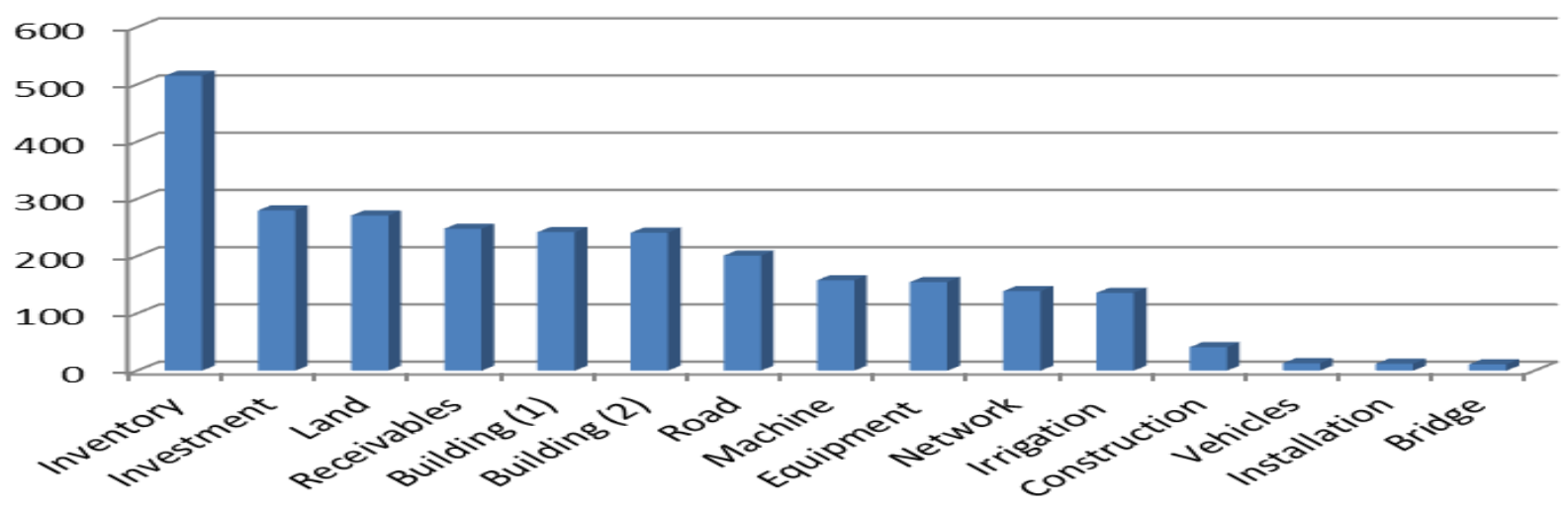

\subsubsection{Liabilities Accounts}

The summary of frequency occurrence in balance sheet report indicates that the obligation/liabilities held the second place as accounts causing local government financial statements to get non-unqualified opinion with 
frequency of appearance 71 times. The problems in the liabilities are related to Account payable in relation with third parties and other short-term debt.

\subsubsection{Equity Accounts}

The summary of frequency occurrence in balance sheet reveals that the equity is the least frequent accounts causing local government financial statements to get opinion besides Unqualified Opinion with frequency of appearance 28 times (see Figure 4).

\subsubsection{Exception in the Statement of Cash Flows}

The word frequency results for each type of financial statements shows that the accounts in the Statement of Cash Flows are the least frequent accounts causing local government financial statements to get nonunqualified opinion with frequency of appearance 693 times (see Figure 1.). The classification based on word frequency is divided into main themes of cash flow statements. This shows that Non Budgetary Activities account is the highest account causing local government financial statements to get Qualified Opinion, Adverse Opinion, and Disclaimer Opinion.

\subsection{Problems of Accounts Causing LGFS Get Non-Unqualified Opinion}

Problems in the accounts causing LGFS obtain Non-Unqualified Opinion are identified based on three major groups of examination findings in accordance with the Technical Instructions Coding of Investigation findings as stated in the SAA Decision No.5/K/I-XIII.2/8/2010. Three groups of these types of investigation findings are: (1) non-compliance with the provisions of laws, (2) the weakness of the internal control system, and (3) In-economies, inefficiency and ineffectiveness (3E). Non-compliance with the provisions of the law including: (a)cause of loss, (b)cause of potential loss, (c)cause of a shortfall, (d) relating to the administration, and (e) cause of criminal offense. Internal control system weaknesses include the findings from (a) the weakness of the accounting and reporting system, (b)the weakness of the budget execution system, and (c)the weakness of the internal control structure. In-economies, inefficiency and ineffectiveness (3E) include investigation findings related to (a) in-economies, (b) inefficiency, and (c) ineffectiveness.

To investigate the problems in the accounts causing LGFS to get Non-Unqualified Opinion, word frequency was run to detect the most frequent keyword associated with three major groups inspection findings according to technical guidelines issued by SAA. After the most frequent words are gained, they are then classified into group of examination findings. Table 3 presents the results of the word frequency analysis into 3 categories of investigation findings. Figure 6 presents the account problems for each category.

Table 3

Category Content Analysis Problems of Exception Accounts

\begin{tabular}{ll}
\multicolumn{1}{c}{ Category } & \multicolumn{1}{c}{ Keyword } \\
\hline Non-compliance with the provisions of law & Non compliance, loss, shortfall, Mistake, Violation, Disserve. \\
$\begin{array}{l}\text { The weakness of the internal control } \\
\text { system }\end{array}$ & Weakness, internal, control, system, structure, truth, validity, doubtfully \\
$\begin{array}{l}\text { In-economies, inefficiency and } \\
\text { ineffectiveness (3E) }\end{array}$ & In-economies, inefficiency, ineffectiveness, infelicity, utilization \\
\hline
\end{tabular}

Figure 6

Recapitulation Frequency of Problems Exception Accounts
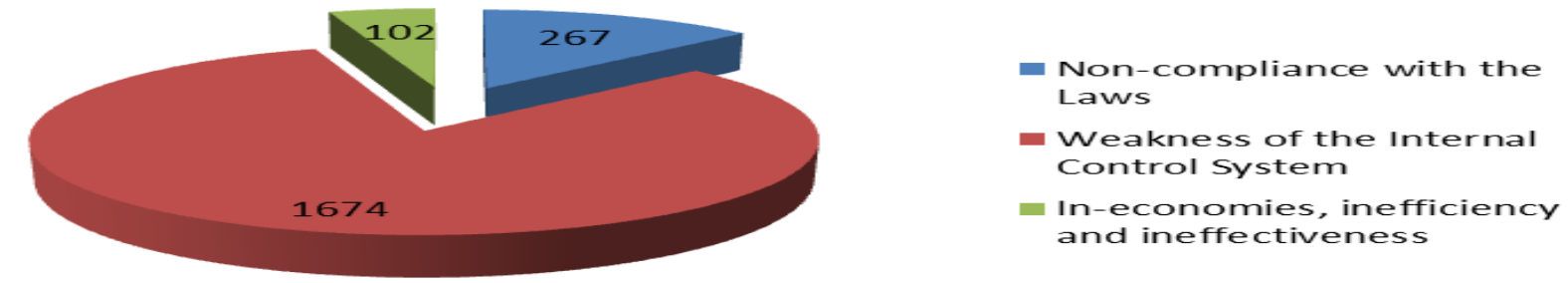

From Figure 6, it can be inferred that the most frequent problem relating to the accounts causing LGFS to get Non-Unqualified Opinion is the weakness of the Internal Control System, followed by non-compliance with the provisions of law and the last is not economical, efficient and effective. 


\subsubsection{Non-Compliance with the Provisions of Laws}

This category is mainly related to the findings that indicate non-compliance with legislation/Laws including: (a) cause of loss b) lead to shortfall, (c) relating to the administration and (d) cause of criminal offense. The results of word frequency related to the exceptions accounts in non-compliance of laws are presented in Figure 7.

Figure 7

Problems Exception Accounts in Non-compliance with the Provisions of Law Category

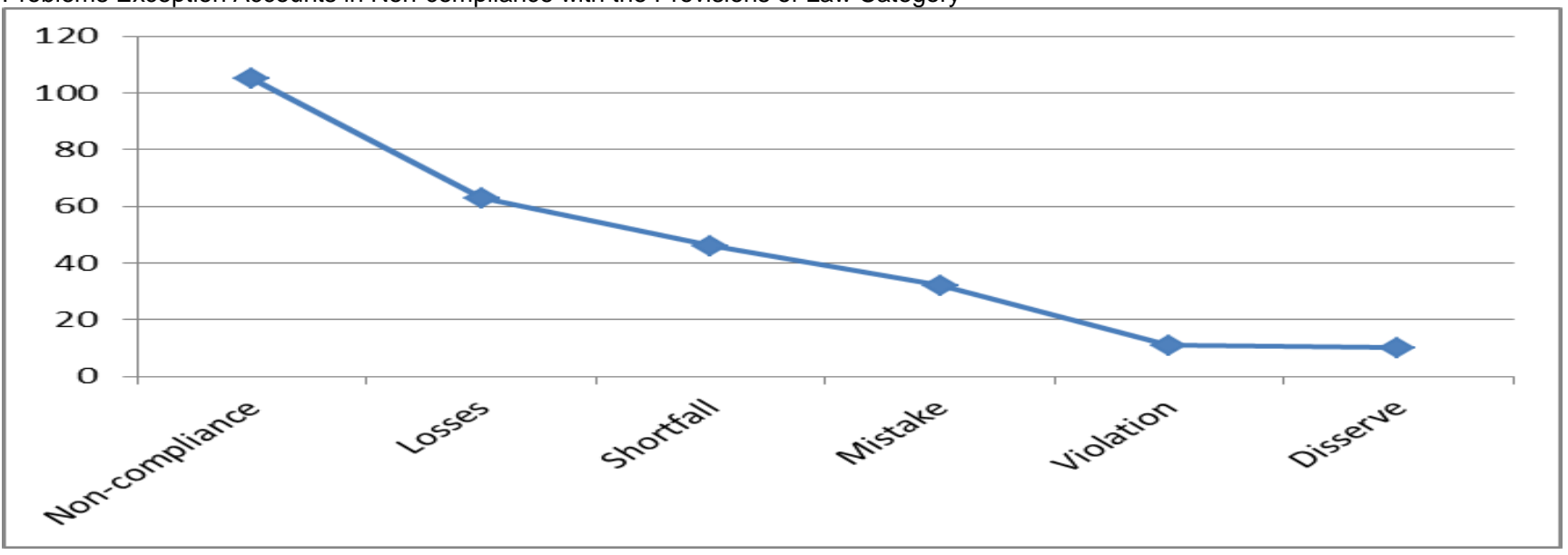

\subsubsection{Internal Control System Weaknesses}

The most frequent problems causing LGFS obtain Non-Unqualified Opinion is internal control weaknesses (see Figure 6). The problems in this category are mainly because of the weakness of the internal control structure, and unreliable accounting and reporting systems. The results of word frequency in the weaknesses of internal control system category is presented in Figure 8.

Figure 8

Problems Exception Accounts in Weakness of The Internal Control System Category

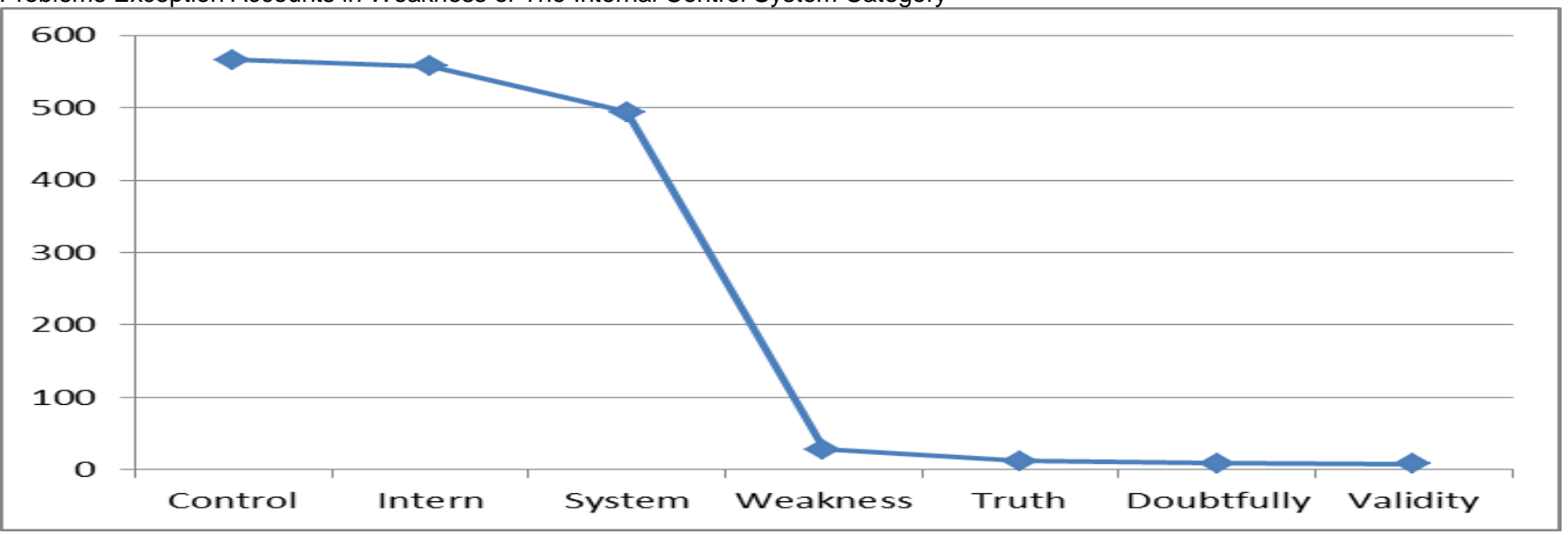

\subsubsection{In-economies, Inefficiencies, and Ineffectiveness (in-3E)}

The results show that the problems for the category in-economies, inefficiency and ineffectiveness are relatively fewer than the other categories. The problem for this category is mainly related to the ineffectiveness and impropriety in the use of the resources. The results of word frequency in this category are presented in Figure 9. 
Figure 9

Problems Exception Accounts in In-economies, inefficiency and ineffectiveness Category

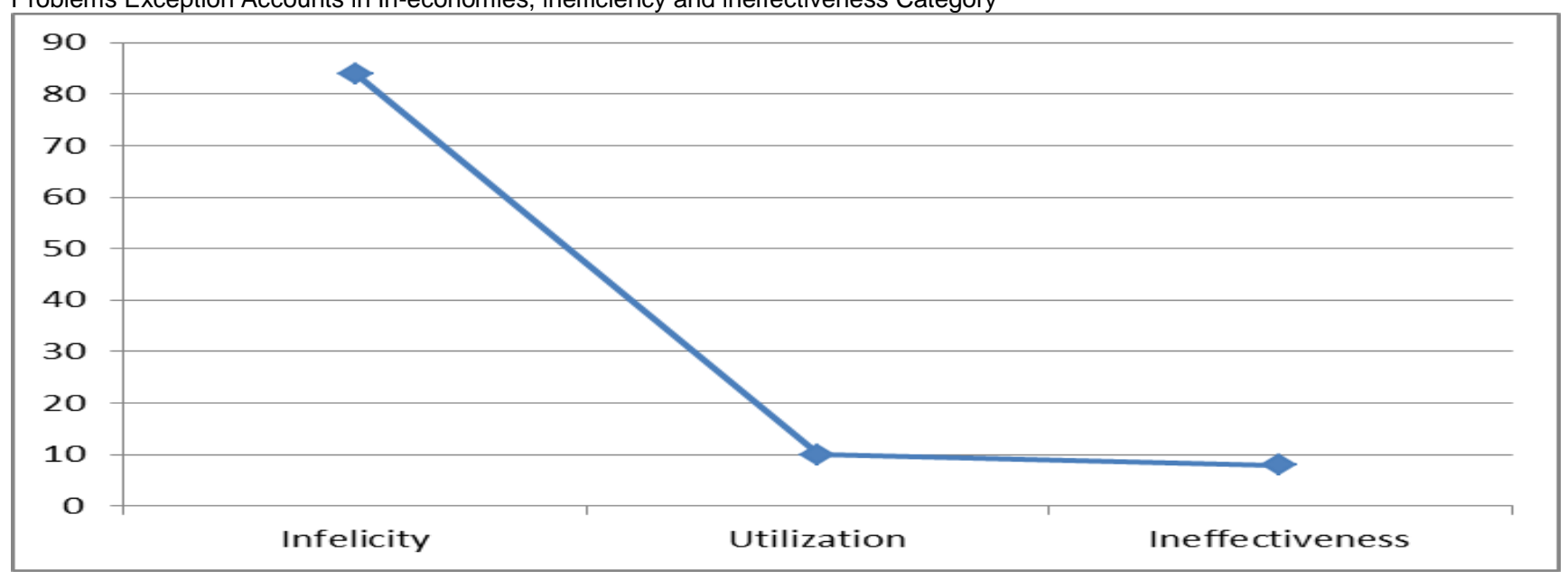

\section{Research Findings and Discussion}

The results of this study point out that the most frequent account as an exception or as a cause of LGFS to get Non-Unqualified Opinion is accounts in the Budget Realization Report. The Balance Sheet accounts are in the second place and the last are the accounts on a Cash Flow statement. These results differ from Subehan's study (2012) which found that the Balance Sheet account was the most frequent account as an exception to the audit opinion. Sari et al. (2010) also suggested different results in which Balance Sheet and Budget Realization accounts were the main cause of LGFS to get Qualified Opinion. Although the account exception for types of financial reports are different from the previous research, but for the category accounts group, the results of this study support the research of Subehan (2012) and Sari et al. (2010) which show that spending accounts and Asset account are the most frequent accounts as an exception for Budget Realization and Balance Sheet. In contrast to Subehan (2012), the results of this current study identified that equity includes accounts that causes LGFS to get Non-Unqualified opinion. These different results are most likely due to the different observation period. By using a longer period (eight years) compared to Subehan's study (2012) which took one year and Sari's et al. (2010) which took 2 years, the results of this study are more thorough in identifying the accounts causing LGFS to get Qualified Opinion, Adverse Opinion and Disclaimer Opinion.

The results of this study identify that the problems for accounts that often appears as an exception are mainly due to the weakness of the Internal Control System, followed by non-compliance with the provision of laws and the latter is a problem related to in-economies, inefficiency and ineffectiveness (not 3E). These results do not support Subehan's (2012) and Sari's et al. (2010) studies which shows that the most frequent problem often appears as an exception is non-compliance with the legislation/laws. Compared to Subehan (2012), this study has found that in-economies, inefficiencies and ineffectiveness (not 3E) also cause LGFS not to obtain Unqualified Opinion.

\section{Research Limitation}

This research was conducted at the Audit Opinion of LGFS for counties and cities Government in East Java implementing Government Accounting Standards with Cash towards Accrual Basis from 2006 to 2013. Thus the results of this study can only describe the conditions that exist in those areas. The data were analyzed aggregately, the researcher did not further analyze the accounts and the problem for each year and in each county or city.

\section{Conclusion}

This study found that the most frequent accounts which appear as an exception in the audit opinion of the LGFS on counties and cities in East Java for 2006-2013 are the accounts on Budget Realization Report. In Budget Realization, the most frequent account which appears as an exception is spending account, while assets found to be the most frequent account as an exception in Balance Sheet. This research also identified that the weakness of the Internal Control System becomes the main problem for accounts that often appears as an exception. 


\section{Research Implications}

The results of this study can be used as an input for local government in managing public funds, especially in terms of the preparation of financial statements to improve the quality of financial reporting. The results of this study also provide an input for policy makers, in this case the central government about variety factors that must be considered before and when implementing the Government Accounting Standards. The results of this study also can be used as reference materials in the development of public sector accounting literature, primarily for government agencies. The results can also be used by various parties who need the information about how to evaluate the activities held by the government.

Future research is recommended to further analyze the accounts and the problems that often appear as an exception in audit opinion for each year and in each county or city. Future studies can also extend the scope of research by involving counties or cities in other provinces in Indonesia in order to obtain a broader picture about the problems considered by SAA in giving opinions on Local Government Financial Statements. Starting in 2015, all of the local government in Indonesia are required to implement the new Government Accounting Standards (GAS) with accrual basis, further research can compare the conditions when implementing GASbased on cash toward accrual basis with the condition when applying GAS with accrual-based.

\section{Glossary}

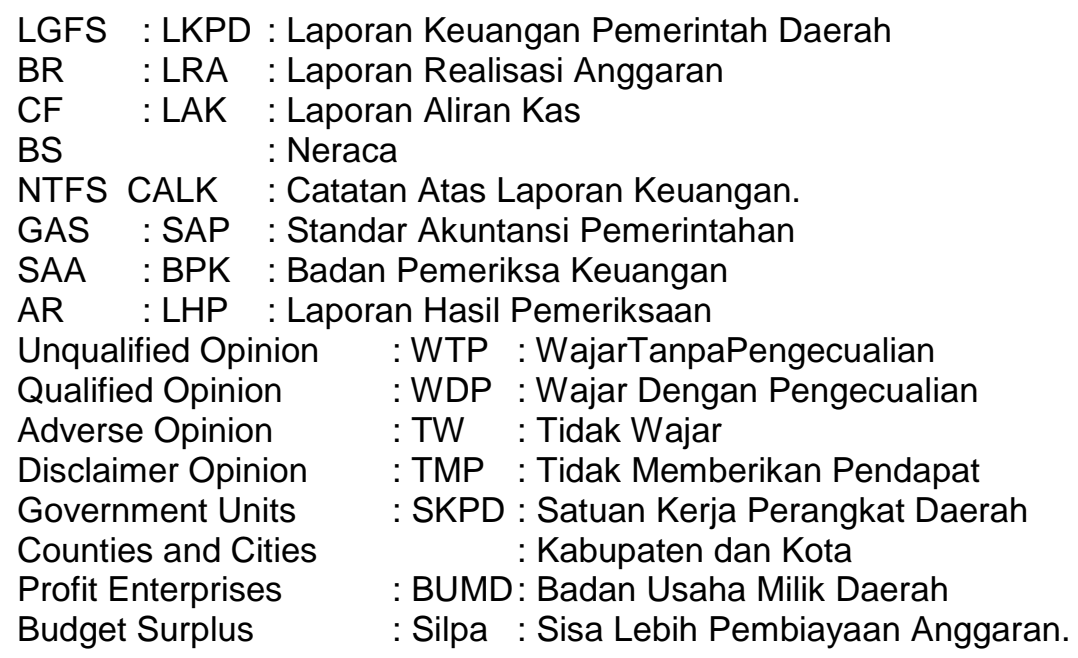

\section{References}

Anthony, R. N., Govindarajan, V., 1995. Management Control Systems Eight Edition. Chicago: Robert D. Irwin. Badan Pemeriksa Keuangan Republik Indonesia, 2007. Ikhtisar Hasil Pemeriksaan Semester I Tahun 2007 atas Laporan Keuangan untuk Tahun Anggaran 2006. 2008. Ikhtisar Hasil Pemeriksaan Semester I Tahun 2008 atas Laporan Keuangan untuk Tahun Anggaran 2007.

2009. Ikhtisar Laporan Hasil Pemeriksaan atas Laporan Keuangan untuk Tahun Anggaran 2008.

2010. Ikhtisar Laporan Hasil Pemeriksaan atas Laporan Keuangan untuk Tahun Anggaran 2009.

, 2011. Ikhtisar Laporan Hasil Pemeriksaan BPK RI atas Laporan Keuangan Pemerintah Daerah Tahun Anggaran 2010.

, 2012. Ikhtisar Laporan Hasil Pemeriksaan BPK RI atas Laporan Keuangan Pemerintah Daerah Tahun Anggaran 2011.

, 2013. Ikhtisar Laporan Hasil Pemeriksaan BPK RI atas Laporan Keuangan Pemerintah Daerah Tahun Anggaran 2012.

, 2014. Ikhtisar Laporan Hasil Pemeriksaan BPK RI atas Laporan Keuangan Pemerintah Daerah Tahun Anggaran 2013.

Churyk, N. T., Lee, C. C., Clinton, B. D., 2008. Can We Detect Fraud Earlier? A Technique Called Content Analysis Raises The Possibility. Strategic Finance, 90 (4).

Godfrey, J., Hodgson, A., Holmes, S., 1997. Accounting Theory. Queensland: John Wiley \& Sons.

Jensen, M., Meckling, W. H., 1976. Theory of the Firm: Managerial Behavior, Agency Cost and Ownership Structure. Journal of Financial Economics 3 (4), 305-360.

John, M. Y., Setiawan, D., 2009. Kiat Memahami Pemeriksaan Laporan Keuangan Pemerintah Daerah di Indonesia. Jakarta: Gramedia Pustaka Utama.

Krippendorff, K., 2004. Content Analysis: An Introduction to Its Methodology Second Edition. Thousand Oaks: Sage Publication. 
Mahmudi, 2007. Analisis Laporan Keuangan Daerah: Panduan Bagi Eksekutif, DPRD, dan Masyarakat dalam Pengambilan Keputusan Ekonomi, Sosial, dan Politik. UPP STIM YKPN.

Mardiasmo, 2006. Akuntansi Sektor Publik. Yogyakarta: Andi.

Moleong, L.J., 2005. Metodologi Penelitian Kualitatif Edisi Revisi. Bandung: Remaja Rosdakarya.

Neuman, W. L., 2011. Social Research Methods: Qualitative and Quantitative Approaches 7th Edition. Pearson Education.

Republik Indonesia, 2004. Undang-Undang Nomor 15 Tahun 2004 tentang Pemeriksaan Pengelolaan dan Tanggungjawab Keuangan Negara.

Republik Indonesia, 2006. Undang-Undang Nomor 15 Tahun 2006 tentang Badan Pemeriksa Keuangan.

Republik Indonesia, 2005. Peraturan Pemerintah Nomor 24 Tahun 2005 tentang Standar Akuntansi Pemerintahan.

Sari, V. F., Rasyid, E. R., Firdaus, 2010. Studi Eksploratif Terhadap Laporan Hasil Pemeriksaan atas Laporan Keuangan Kabupaten/Kota yang Memperoleh Opini Wajar dengan Pengecualian Menggunakan Content Analysis. Proceeding Simposium Nasional Akuntansi XIII.

Shauki, E. R., 2014. Using Research Instruments. Lecturing, University of South Australia/University of Indonesia.

Subehan, T., 2012. Evaluasi Atas Laporan Keuangan Pemerintah Daerah Yang Tidak Memperoleh Opini Wajar Tanpa Pengecualian: Studi Pada Laporan Keuangan Pemerintah Daerah Se-Jawa Timur Tahun Anggaran 2011. Tesis, Pasca Sarjana Universitas Pembangunan Nasional "Veteran" JawaTimur.

Watts, R.L., Zimmerman, J.L., 1986. Positive Accounting Theory. Englewood Cliffs: Prentice-Hall. 